\title{
Types of Evaluation
}

Once you've determined which program activities in your logic model should be evaluated, you can begin to identify the types of evaluation you can conduct.

\section{What are the most common types of evaluation?}

There are several types of evaluations that can be conducted. Some of them include the following:

- Formative evaluation ensures that a program or program activity is feasible, appropriate, and acceptable before it is fully implemented. It is usually conducted when a new program or activity is being developed or when an existing one is being adapted or modified.

- Process/implementation evaluation determines whether program activities have been implemented as intended.

- Outcome/effectiveness evaluation measures program effects in the target population by assessing the progress in the outcomes or outcome objectives that the program is to achieve.

- Impact evaluation assesses program effectiveness in achieving its ultimate goals.

Process Evaluation determines whether program activities have been implemented as intended and resulted in certain outputs. You may conduct process evaluation periodically throughout the life of your program and start by reviewing the activities and output components of the logic model (i.e., the left side).

Results of a process evaluation will strengthen your ability to report on your program and use information to improve future activities. It allows you to track program information related to Who, What, When and Where questions:

- To whom did you direct program efforts?

- Where did your program activities take place?

- What has your program done?

- When did your program activities take place?

- What are the barriers/facilitators to implementation of program activities?

Outcome Evaluation measures program effects in the target population by assessing the progress in the outcomes that the program is to address. To design an outcome evaluation, begin with a review of the outcome components of your logic model (i.e., the right side).

Some questions you may address with an outcome evaluation include:

- Were medical providers who received intensive STD training more likely to effectively counsel, screen and treat patients than those who did not?

- Did the implementation of STD counseling in community-based organizations result in changes in knowledge, attitudes, and skills among the members of the target population?

- Did the program have any unintended (beneficial or adverse) effects on the target population(s)?

- Do the benefits of the STD activity justify a continued allocation of resources?

For more information and examples, see Step 3.1 in the Practical Use of Program Evaluation among STD Programs manual.

http://www.cdc.gov/std/program/pupestd.htm 


\section{Types and Uses of Evaluation}

In order to plan the evaluation in accord with the most appropriate evaluation method, it is necessary to understand the difference between evaluation types. There are a variety of evaluation designs, and the type of evaluation should match the development level of the program or program activity appropriately. The program stage and scope will determine the level of effort and the methods to be used.

\begin{tabular}{|c|c|c|c|}
\hline Evaluation Types & When to use & What it shows & Why it is useful \\
\hline $\begin{array}{l}\text { Formative Evaluation } \\
\text { Evaluability Assessment } \\
\text { Needs Assessment }\end{array}$ & $\begin{array}{l}\text { - During the development of a } \\
\text { new program. } \\
\text { - When an existing program is } \\
\text { being modified or is being used } \\
\text { in a new setting or with a new } \\
\text { population. }\end{array}$ & $\begin{array}{l}\text { - Whether the proposed program } \\
\text { elements are likely to be needed, } \\
\text { understood, and accepted by the } \\
\text { population you want to reach. } \\
\text { - The extent to which an evaluation } \\
\text { is possible, based on the goals and } \\
\text { objectives. }\end{array}$ & $\begin{array}{l}\text { - It allows for modifications to } \\
\text { be made to the plan before } \\
\text { full implementation begins. } \\
\text { - Maximizes the likelihood that } \\
\text { the program will succeed. }\end{array}$ \\
\hline $\begin{array}{l}\text { Process Evaluation } \\
\text { Program Monitoring }\end{array}$ & $\begin{array}{l}\text { - As soon as program } \\
\text { implementation begins. } \\
\text { - During operation of an existing } \\
\text { program. }\end{array}$ & $\begin{array}{l}\text { - How well the program is working. } \\
\text { - The extent to which the program is } \\
\text { being implemented as designed. } \\
\text { - Whether the program is accessible an } \\
\text { acceptable to its target population. }\end{array}$ & $\begin{array}{l}\text { - Provides an early warning for } \\
\text { any problems that may occur. } \\
\text { - Allows programs to monitor } \\
\text { how well their program plans } \\
\text { and activities are working. }\end{array}$ \\
\hline $\begin{array}{l}\text { Outcome Evaluation } \\
\text { Objectives-Based } \\
\text { Evaluation }\end{array}$ & $\begin{array}{l}\text { - After the program has made } \\
\text { contact with at least one person } \\
\text { or group in the target population. }\end{array}$ & $\begin{array}{l}\text { - The degree to which the program } \\
\text { is having an effect on the target } \\
\text { population's behaviors. }\end{array}$ & $\begin{array}{l}\text { - Tells whether the program is } \\
\text { being effective in meeting it's } \\
\text { objectives. }\end{array}$ \\
\hline $\begin{array}{l}\text { Economic Evaluation: } \\
\text { Cost Analysis, } \\
\text { Cost-Effectiveness Evaluation, } \\
\text { Cost-Benefit Analysis, } \\
\text { Cost-Utility Analysis }\end{array}$ & $\begin{array}{l}\text { - At the beginning of a program. } \\
\text { - During the operation of an } \\
\text { existing program. }\end{array}$ & $\begin{array}{l}\text { - What resources are being used in a } \\
\text { program and their costs (direct and } \\
\text { indirect) compared to outcomes. }\end{array}$ & $\begin{array}{l}\text { - Provides program managers } \\
\text { and funders a way to assess } \\
\text { cost relative to effects. "How } \\
\text { much bang for your buck." }\end{array}$ \\
\hline Impact Evaluation & $\begin{array}{l}\text { - During the operation of an } \\
\text { existing program at appropriate } \\
\text { intervals. } \\
\text { - At the end of a program. }\end{array}$ & $\begin{array}{l}\text { - The degree to which the program } \\
\text { meets its ultimate goal on an overall } \\
\text { rate of STD transmission (how } \\
\text { much has program X decreased the } \\
\text { morbidity of an STD beyond the study } \\
\text { population). }\end{array}$ & $\begin{array}{l}\text { - Provides evidence for use in } \\
\text { policy and funding decisions. }\end{array}$ \\
\hline
\end{tabular}

It is important to note the usefulness of conducting process evaluation while you are implementing outcome evaluation. If the outcome evaluation shows that the program did not produce the expected results, it may be due to program implementation issues. Therefore, it is recommended that if you conduct outcome evaluation, you also implement process evaluation.

TIP: Learn more about types of evaluations in the Program Operations Guidelines for STD Prevention manual on program evaluation. http://www.cdc.gov/std/program/ProgEvaluation.pdf 